\title{
Nucleotide sequence and structural organization of the small, broad-host-range plasmid pCl411 from Leuconostoc lactis 533
}

\author{
Aidan Coffey, ${ }^{1,2}$ Aidan Harrington, ${ }^{1}$ Karen Kearney, ${ }^{1}$ Charles Daly ${ }^{1,2}$ \\ and Gerald Fitzgerald ${ }^{1}$
}

Author for correspondence: Gerald Fitzgerald. Tel: +35321276871 ext. 2730. Fax: + 35321275934

Food Microbiology

Department ${ }^{1}$ and National

Food Biotechnology Centre? University College, Cork, Ireland

\begin{abstract}
The nucleotide sequence of the Leuconostoc lactis 533 cryptic plasmid pCI411 (2926 bp) was determined. Analysis revealed the presence of three open reading frames (ORFs). ORF 1 was capable of encoding a $24.9 \mathrm{kDa}$ peptide which shared homology with the replication initiation protein (RepB) from a number of Gram-positive rolling circle plasmids. ORF 2 could encode a peptide of $6.6 \mathrm{kDa}$ which was homologous to the RepC protein of the lactococcal plasmid pWV01. A function could not be assigned to ORF 3, which was capable of encoding a $12 \cdot 1 \mathrm{kDa}$ peptide. Transcription-translation analysis indicated the presence of three peptides of the predicted molecular masses. A putative double strand origin of replication (DSO) was identified which showed strong similarity with the DSO of a number of Gram-positive plasmids including pE194 from Staphylococcus. Structural analysis identified a number of direct and indirect repeats in addition to putative recombination-specific sites ( $\mathbf{R S}_{\mathrm{A}}$ and $\mathrm{RS}_{\mathrm{B}}$ ) in the non-coding region of $\mathrm{pCl} 411$. The observed characteristics suggest that this plasmid replicates using the rolling circle mechanism. pCl411, which could be introduced into Leuconostoc, Lactococcus, Streptococcus, Lactobacillus and Bacillus is the first plasmid from the genus Leuconostoc to be characterized in such detail.
\end{abstract}

Keywords: Leuconostoc lactis, cryptic plasmid

\section{INTRODUCTION}

The genus Leuconostoc represents a diverse group of heterofermentative lactic acid bacteria of considerable industrial importance. Traditionally, they have been used with other lactic acid bacteria in various food and wine fermentations where, in many cases, a number of beneficial qualities result from the dominance of Leuconostoc species (Mathieu et al., 1993). For example, in dairy fermentations, the ability of some Leuconostoc species to produce diacetyl and carbon dioxide is important because of their contribution to flavour and eye-hole formation in Dutch-type cheeses. Like other lactic acid bacteria, many Leuconostoc species harbour one or more natural plasmids of various sizes. To date, phenotypes such as lactose utilization

Abbreviations: SSO, single strand origin; DSO, double strand origin; RS, recombination-specific site; $\mathrm{RC}$, rolling circle.

The GenBank accession number for the nucleotide sequence reported in this paper is L25529.
(David et al., 1992), citrate permease activity (David, 1992) and bacteriocin production and immunity (Hastings et al., 1991) have been plasmid-linked in this genus but the majority of plasmids have no known function.

The study of small plasmids from a variety of bacteria has recently become a focus of research interest and in several cases this work has led to the development of families of vectors designed for specific purposes. The genetic organization and mode of replication of a number of small cryptic plasmids from some lactic acid bacteria have been described recently (Bates \& Gilbert, 1989; Leer et al., 1992; Xu et al., 1991), and it is now known that these replicons are broadly similar to those from other Grampositive (Gruss \& Ehrich, 1989) and Gram-negative (Yang \& McFadden, 1993) bacteria which replicate via single-stranded intermediates. They are collectively referred to as rolling circle (RC) plasmids. All RC plasmids harbour a gene encoding a plasmid replication initiationtermination protein (Rep), its target site, termed the double strand origin (DSO, formerly plus origin), and a 
Table 1. Bacterial strains and plasmids

\begin{tabular}{|c|c|c|}
\hline Strain or plasmid & Characteristics & Reference/source \\
\hline \multicolumn{3}{|l|}{ Leuconostoc lactis } \\
\hline 533 & Wild-type strain & UCC culture collection \\
\hline 532 & Wild-type strain & UCC culture collection \\
\hline $\mathrm{N} 2$ & Wild-type strain & UCC culture collection \\
\hline NCW1 & Wild-type strain & UCC culture collection \\
\hline $7-1$ & Wild-type strain & UCC culture collection \\
\hline $\mathrm{AH} 022$ & Plasmid-free derivative of 532 & This study \\
\hline $\mathrm{AH} 211$ & AH022 containing pCI214 $\left(\mathrm{Em}^{\mathrm{R}}\right)$ and pCI411 & This study \\
\hline AH+11 & AH211 cured of pCI214 & This study \\
\hline AH431 & AH022 containing pCI431 & This study \\
\hline \multicolumn{3}{|c|}{$\begin{array}{l}\text { Leuconostoc mesenteroides subsp. } \\
\text { mesenteroides }\end{array}$} \\
\hline $\mathrm{X} 2$ & Wild-type strain & UCC culture collection \\
\hline 523 & Wild-type strain & UCC culture collection \\
\hline NCDO2028 & Wild-type strain & UCC culture collection \\
\hline \multicolumn{3}{|c|}{ Leuconostoc paramesenteroides } \\
\hline NCDO1612 & Wild-type strain & UCC culture collection \\
\hline \multicolumn{3}{|c|}{ Lactococcus lactis subsp. lactis } \\
\hline MG1614 & $\mathrm{Sm}^{\mathrm{R}}$, plasmid-free derivative of $L$. lactis subsp. lactis 712 & Gasson (1983) \\
\hline \multicolumn{3}{|l|}{ Lactobacillus casei } \\
\hline 20012 & Wild-type strain & UCC culture collection \\
\hline \multicolumn{3}{|l|}{ Bacillus subtilis } \\
\hline DB104 & & Vehmaanperä (1989) \\
\hline \multicolumn{3}{|c|}{$\begin{array}{l}\text { Streptococcus salivarius subsp. } \\
\text { thermophilus }\end{array}$} \\
\hline 054 & & Courtesy of A. Mercenier \\
\hline \multicolumn{3}{|l|}{ Escherichia coli } \\
\hline V517 & Source of size reference plasmids & Macrina et al. (1978) \\
\hline TG1 & $\begin{array}{l}\sup E \Delta(\text { lac-pro } A B) \text { bsd } \Delta 5 \mathrm{~F}^{\prime} \operatorname{traD} 36\left(r_{k}^{-} m_{m}^{-}\right) \text {pro } A B^{+} \\
\text {lac } I^{q} \text { lac Z } \Delta \mathrm{M} 15\end{array}$ & Sambrook et al. (1989) \\
\hline HB101 & $\begin{array}{l}\mathrm{F}^{\prime} \text { bsdS } 20\left(r_{b}^{-} m_{b}^{-}\right) \text {rec } A 13 \text { ara-14 pro A2 lac Y'1 galK2 rpsL20 } \\
\left(S m^{R}\right) x y l-5 \text { mtl-1 supE44 }\end{array}$ & $\begin{array}{l}\text { Boyer \& Roulland-Dussoix } \\
(1969)\end{array}$ \\
\hline \multicolumn{3}{|l|}{ Plasmids } \\
\hline pCI341 & $3.1 \mathrm{~kb}$ replication probe vector, $\mathrm{Cm}^{\mathrm{R}}$ & Hayes et al. (1990) \\
\hline $\mathrm{pNZ12}$ & $4.3 \mathrm{~kb} \mathrm{RC}$ plasmid & Hayes et al. (1991) \\
\hline pCI214 & $29 \mathrm{~kb} \mathrm{Em}^{\mathrm{R}}$ plasmid & Caplice et al. (1987) \\
\hline pCI411 & 2.7 kb Cryptic plasmid from Leuc. lactis 533 & This study \\
\hline $\mathrm{pCI} 430$ & $2.3 \mathrm{~kb}$ HincII fragment of pCI411 cloned in pCI341 (Rep $\left.{ }^{-}\right)$ & This study \\
\hline pCI431 & SstI-linearized pCI411 cloned in pCI341 $\left(\operatorname{Rep}^{+}\right)$ & This study \\
\hline pCI432 & $\begin{array}{l}\text { Excision of } 1.4 \mathrm{~kb} \mathrm{HpaI-Ss} \text { I region of } \mathrm{pCI} 411 \text { from pCI } 431 \\
\left(\text { Rep }^{-}\right)\end{array}$ & This study \\
\hline
\end{tabular}

specific sequence known as the single strand origin (SSO, formerly minus origin) which makes possible the conversion of ssDNA intermediates into dsDNA plasmid molecules. A different genetic organization is observed in plasmids which replicate using the theta mechanism (Hayes et al., 1991). In the genus Leuconostoc, there have been no reports concerning the mode of replication and stability of plasmid molecules. In this paper, we describe the cloning and sequence analysis of the cryptic plasmid pCI411 (2926 bp) from Leuconostoc lactis 533 (type species). Its genetic organization and mode of replication is deduced, and its host range, stability and homology with other plasmids are examined.

\section{METHODS}

Bacterial strains and plasmids. All bacterial strains and plasmids used in this study are listed in Table 1. Leuconostoc strains were routinely subcultured in modified MRS (mMRS) broth (Difco) at $30^{\circ} \mathrm{C}$. Lactococcus lactis subsp. lactis MG1614 was grown at $30^{\circ} \mathrm{C}$ in M17 medium (Terzaghi \& Sandine, 1975) in which glucose $(0.5 \%, \mathrm{w} / \mathrm{v})$ replaced lactose (GM17). Escherichia coli strains were grown in L broth (Sambrook et al., 1989 ) with shaking at $37^{\circ} \mathrm{C}$. Bacillus subtilis was grown in LB medium at $30^{\circ} \mathrm{C}$. Selective media contained antibiotics at the following concentrations: vancomycin, $100 \mu \mathrm{g} \mathrm{ml}^{-1}$; chloramphenicol, $10 \mu \mathrm{g} \mathrm{ml}^{-1}$ for E. coli and Lactobacillus casei, $5 \mu \mathrm{g} \mathrm{ml}^{-1}$ for Leuconostoc strains, Lc. lactis subsp. lactis and B. subtilis, and 
$3.5 \mu \mathrm{g} \mathrm{mi} \mathrm{m}^{-1}$ for Streptococcus salivarius subsp. thermophilus. Ampicillin $\left(50 \mu \mathrm{g} \mathrm{m}^{-1}\right)$ was used to maintain pUC19 in E. coli, and erythromycin $\left(5 \mu \mathrm{g} \mathrm{ml}^{-1}\right)$ to maintain pCI214 in Leuconostoc.

DNA preparation and plasmid analysis. For rapid preparations of plasmid DNA from Leuconostoc, Streptococcus and Lactococcus strains the method of Anderson \& McKay (1983) was used, with the following modifications for Leuconostoc species: cells resuspended in TES buffer $[50 \mathrm{mM}$ Tris/ $\mathrm{HCl}$ (pH 8.0); $1 \mathrm{mM}$ EDT A, $6.7 \%(\mathrm{w} / \mathrm{v})$ sucrose] were treated with $15 \mathrm{mg}$ lysozyme $\mathrm{ml}^{-1}$ in $25 \mathrm{mM}$ Tris $/ \mathrm{HCl}(\mathrm{pH} 8.0)$ at $37^{\circ} \mathrm{C}$ for $15 \mathrm{~min}$. After treatment with sodium dodecyl sulfate $(20 \%, w / v$ in $50 \mathrm{mM}$ Tris/ $\mathrm{HCl} ; 20 \mathrm{mM}$ EDTA, $\mathrm{pH} \mathrm{8.0)}$, the suspension was left to clear for $20 \mathrm{~min}$ at $37^{\circ} \mathrm{C}$. Plasmid DNA was isolated from Lb. casei as described by Chassy \& Flickinger (1987). For lysis of E. coli and B. subtilis, the method of Birnboim \& Doly (1979) was used. Preparative amounts of plasmid DNA were obtained by scaling up these procedures followed by caesium chloride/ ethidium bromide density gradient ultracentrifugation.

Restriction endonuclease analysis, molecular cloning techniques and nucleotide sequence analysis. Restriction endonucleases were purchased from Boehringer. DNA digestion and general cloning procedures were as outlined by Sambrook $e t a l$. (1989). Restriction analysis was performed as described previously (Coffey et al., 1991). pCI411 DNA fragments generated using Dral, HindII, SstI, HpaI and HaeIII were cloned into E. coli TG1 using $\mathrm{pUC19}$. The nucleotide sequence was determined by sequencing double-stranded plasmid DNA in two orientations by the dideoxy chain termination method (Sanger et al., 1977), using Sequenase version 2.0 (United States Biochemicals) and TaqTrack (Promega). Synthetic 17 -mer DNA primers were prepared on a DNA synthesizer (Applied Biosystems). LaserGene (DNASTAR) and MicroGenie (Beckman) were used for computer-assisted sequence analysis.

Electroporation and transformation. E. coli electro-transformation was performed using a Gene Pulser apparatus and the conditions outlined in the manufacturer's instruction manual (Bio-Rad). Leuconostoc cultures were prepared for electrotransformation as follows. Cultures were grown overnight at $30^{\circ} \mathrm{C}$ in mMRS broth supplemented with $40 \mathrm{mM}$ DL-threonine and then diluted $(1: 50)$ in fresh broth and grown at $30^{\circ} \mathrm{C}$ for 3-4 h. Cells were harvested by centrifugation at $4{ }^{\circ} \mathrm{C}$, washed twice in ice-cold $10 \%(\mathrm{w} / \mathrm{v})$ sucrose (Sigma), resuspended in 0.01 culture volume of ice cold $10 \%$ sucrose and held on ice until required. Up to 0.1 volume of plasmid DNA was thoroughly mixed with $100 \mu \mathrm{l}$ of cell suspension in a chilled Gene Pulser cuvette (electrode separation of $2 \mathrm{~mm}$ ). Cells were exposed to a single electric pulse (peak voltage $2.5 \mathrm{kV}$; capacitance $25 \mu \mathrm{F}$; resistance $200 \Omega$ ) which generated a peak field strength of $12.5 \mathrm{kV} \mathrm{cm}^{-1}$. Immediately after delivery of the pulse, the cells were added to $5 \mathrm{ml} \mathrm{mMRS}$ broth and incubated at $30{ }^{\circ} \mathrm{C}$ for $2 \mathrm{~h}$ prior to spreading on mMRS agar plates containing the relevant antibiotics. Colonies were visible after $48 \mathrm{~h}$. Strep. salivarius subsp. thermophilus 054 was elecro-transformed as described by Slos et al. (1991), Lc. lactis subsp. lactis M(;1614 as described previously (Coffey et al., 1991), Lb. casei 20012 as described by Chassy \& Flickinger (1987) and B. subtilis DB104 as described by Vehmaanperä (1989).

Southern hybridizations. After fractionation on $0.7 \%$ agarose gels, DNA was transferred to nitrocellulose filters by the method of Southern (1975). DNA was labelled using the enhanced-chemiluminance (ECL) gene detection system (Amersham). Probe labelling, hybridization and washing steps were done according to the manufacturer's instructions.

Detection of SSDNA in whole-cell lysates of Lc. lactis and
Leuconostoc. This was achieved using the method described by Leenhouts et al. (1991).

In vitro transcription-translation analysis. Protein products of pCI411 were identified from in vitro transcription-translation studies using a prokaryotic DNA-directed translation kit (Amersham) based on an S30 cell extract from E. coli. ${ }^{35} \mathrm{~S}-$ labelled proteins were electrophoresed on $0 \cdot 1 \%$ SDS $/ 15 \%$ polyacrylamide gels. Gels were fixed in $7 \%(\mathrm{v} / \mathrm{v})$ acetic acid, impregnated with Amplify (Amersham), dried and exposed to Hyperfilm MP autoradiography film (Amersham) for 48-96 h with an intensifying screen. ${ }^{14} \mathrm{C}$-methylated proteins (Amersham) were used as molecular mass markers.

\section{RESULTS AND DISCUSSION}

\section{Isolation and characterization of pCl411}

Leuconostoc lactis 533 is the type strain of this species (Garvie, 1986) and contains two plasmids of $12.5 \mathrm{~kb}$ and $2.9 \mathrm{~kb}$, the latter designated pCI411. Total plasmid DNA was isolated from this strain and co-transformed with the $12 \cdot 4 \mathrm{~kb}$ erythromycin resistance plasmid pCI214 (Caplice et al., 1987) into the plasmid-free Leuc. lactis AHO22. $\mathrm{Em}^{\mathbf{R}}$ transformants were obtained at a frequenty of $3.52 \times$ $10^{4}(\mu \mathrm{g} \mathrm{DNA})^{-1}$, of which $11 \%$ were shown to harbour pCI411. Repeated subculture at $37{ }^{\circ} \mathrm{C}$ was used to cure the marker plasmid from $\mathrm{Em}^{\mathrm{R}}$ transformants. A representative derivative containing pCI411 alone was designated Leuc. lactis AH411. A map of pCI411 showing relevant restriction sites is presented in Fig. 1. In order to locate the genetic elements necessary for replication of pCI411, various constructs were generated by subcloning parts or all of the plasmid into the replication probe vector $\mathrm{pCI} 341$ (Hayes et al., 1990), whose replication in E. coli HB101 is

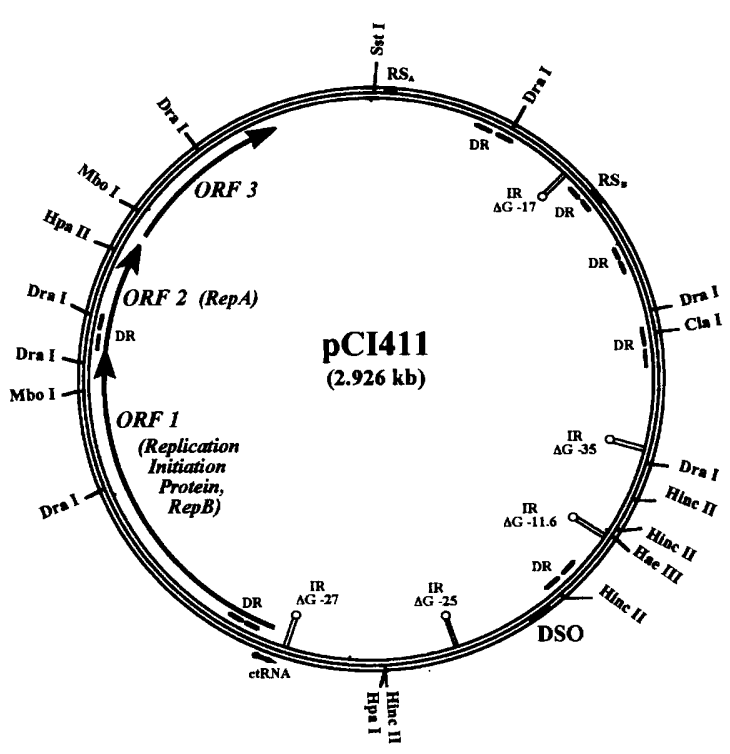

Fig. 1. Map of $\mathrm{pCl} 411$ showing relevant restriction sites used for cloning and location of features derived from nucleotide sequence analysis: open reading frames (ORF), inverted repeat structures (IR) with $\Delta G$ values, direct repeats (DR), location of putative double strand origin (DSO) and recombination sequences (RS). 
Recombination Sequencela

GAGCTCACACTPTATAACAT FAGTATAGTGAGTIATACTH GATGCCGTPTATCAGGAACGTAAGTACGGCAGAGAGGACATAAACAAAGAGACTGGTG

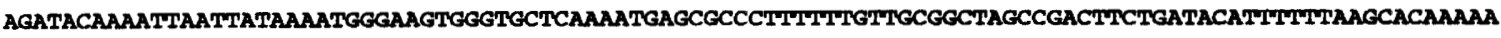

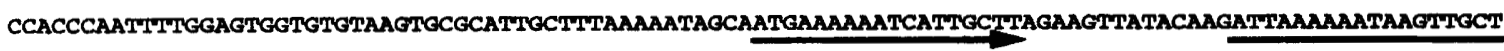
TPATTGACGTTGAGCTTCGGATCCTPAACAATCCCAAAACTTGTCGAATGGTCGGCTYPAMTAGCTCACGCTACGCCGACATTCGTCTTCAAGTTTAGTT AAGGGTTCTHCTCAACATAAA HAMTITCTCGGCATAAFTGTGTCATAAACTAATAGAAAAGTGCATPATAGTCATAATCAAAGTPAATAAACAAGC TAATAACGTAACATTACGAGCTTHGGTFGTGTTCTGATFCCCATTTCTATATTCTTTCATAACAAATAACCAAGAAAGAATTACTAAAATTCCTAAAATA

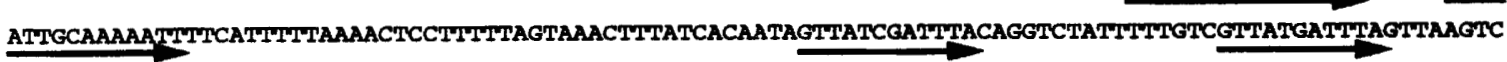
CCATAAGGGTGCACTTATACTCTAAATAAATTGGAGTTGTGCTAAAACACTPGAACCTGPATCAGATPTCACTHTGCTCAAACAAAACTGACTITCGTCA GTIGGATCTPCAAAGCCGATAAAGTCCAGTCGCCAACTCCTCCAGACPTATCGGCITTGAAGATTGCTIPTAAATGCCTCTAATITGCTCTCTAAGCCA THITIAGCTGTIACCTGTATAATTPACTGTCCGTCAACGGTAAATCGACGTAGAACGGCIPTHAGCCGITCTGGGAGGCTITAAGGAGTGACGGACTCGC TAGGCCAAGACACTPPTGCGCATGCAAAGAAAAGCAACCCTGCTPTPTHTGCCTGCCTCACGGCGAGTGCGGGGTGAGTHTGAGCGGGGCTCCCTATCT ATAGGCGGTCAAGCTGGCGCACGTTGGACTGGGTTPGGGGCGTCAACCATGATHTTGATITGGTITGAGTGGGATAAAAATMGGAGAAAAACATGGGG

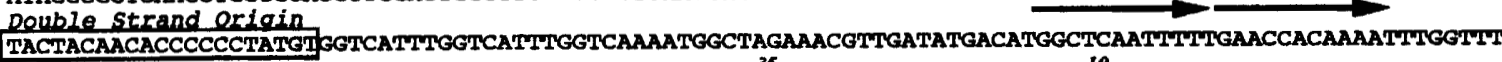

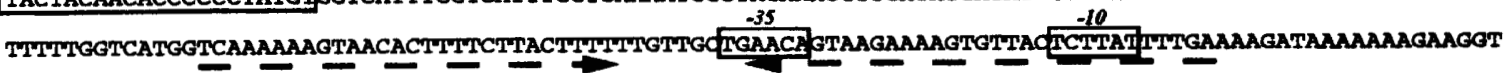
GGTGGTCATHTGGTAAGCAATGATAAAAMAGAGTGATGTTAACTCTAACAAAGAAGTTGCTGATGATPTAGAAAAAATGCAAAAMGTATGGGTPA

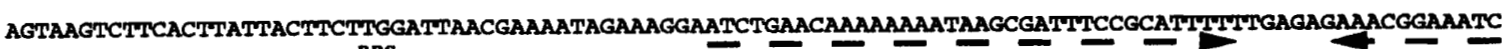

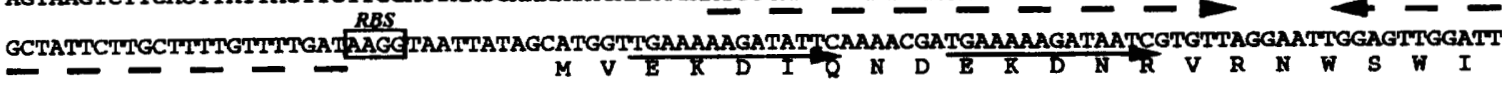
GTATATCCTGAATCAGCTCCTGAAAATGGAGACAATTGITAGATGAAACAGGAGAAAATGGATAGAAAGCCCACTGCATGATAAAGATATAAACGAAA

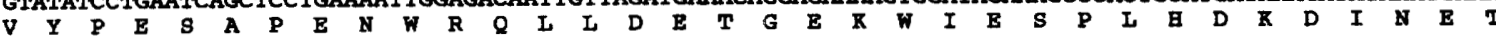
CGACTGATGAAATAAAAAACCTCACTGGCATATAATAATTTCGTHACTAACAAAAAAAGCTATAAACAAGCGTMATATATCTCTGAAATGATGATGC

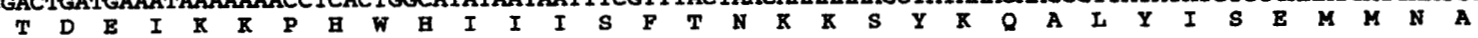
ACCAGAACCAAAAAAATTGCTAGTTTACAAGGTTCAGTTCAATATTPGTGGCACAGAAACAATCCTGAAAAGATCAGTATGATAAAAGTGAAGTTGT'

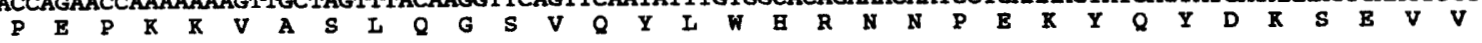
GCTCATAATGGTTMAATATCGTCAATATTPACAGATGTMGAGTAGATACGGATGTCATTCTGCAAGAAATAGTGCAATGGATTCGTGAATCTAACT

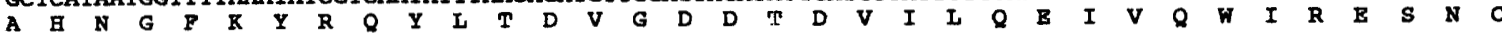
GTPATGAATATGGGGATTAGTTGATATGCTGTATCTGAAAAGTCGATGATTGGTTCCCACCGITAGAAGTCAAACGATCTITHTAACTGCTTATCT

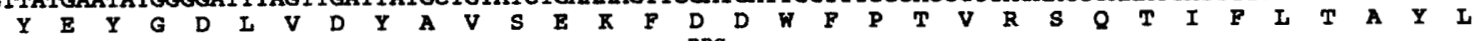

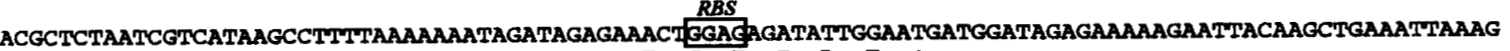

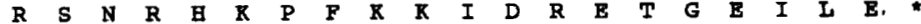

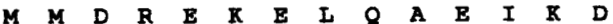

ATTTAAAAAAAGGAACGAAGATTAAAAAAGGAATTGAGAGATATAGGGAAATGAAGTGGAATATCAACGGAAGITGATTHACTGAGTIATACITT

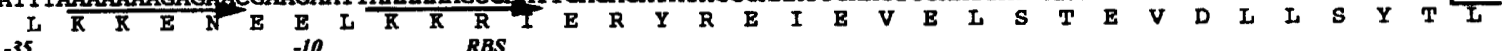

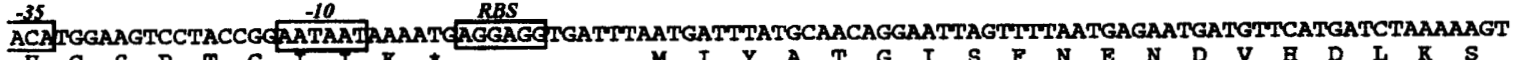

ATTGTCAAATTAAGTTAGAATCAACCGAAGATGAAACTTGACAGTTGATGATGAAAAAATCAGGGATGGTACAAAAAAGAAGCTATCATATHTGGC

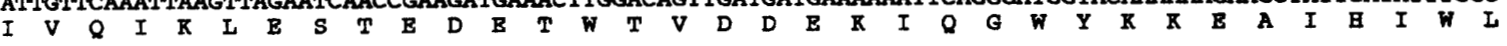
TCAAATCAAAAGGAGAACAAGGATTAAAATAAAGTTAAATTATCTCCATATPCTGAGTHAGAAGCTGTCGAAGTAATGGTGTTAAATATGTTCGCGC

Fig. 2. Nucleotide sequence of plasmid $\mathrm{pCl} 411$ and predicted amino acid sequences of ORFs 1,2 and 3 . Boxed, recombination sequences $R_{A}$ and $R S_{B}$, putative double strand origin, -10 and -35 sequences, and ribosome-binding sites (RBS); horizontal solid arrows, direct repeats; horizontal dashed arrows, inverted repeats; *, stop codons.

supported by the pBR322 replicon, which is not functional in the Leuconostoc background. Thus the isolation of $\mathrm{Cm}^{\mathrm{R}}$ transformants in Leuc. lactis AH022 implied that a functional pCI411 replicon was present (Table 1). Cloning of the entire plasmid using the unique $S_{s t} \mathrm{I}$ site and subsequent transformation into $E$. coli resulted in the isolation of pCI431, which was the only recombinant plasmid which could also replicate in Leuconostoc $\left(\operatorname{Rep}^{+}\right)$. When parts of pCI411 DNA were removed, generating the constructs pCI430 and pCI432 (Table 1 and Fig. 1), the ability to replicate was abolished, indicating that the region from HincII (934) to HincII (1442) and HpaI (1442) to Sst (2926) contained DNA which was essential for plasmid replication. 


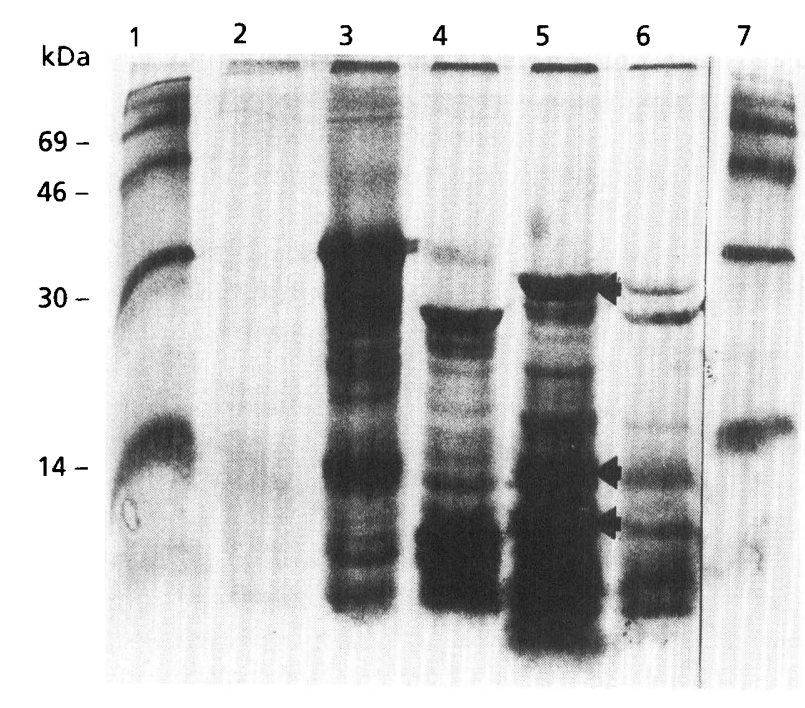

Fig. 3. Transcription-translation analysis of plasmids. Lanes: 1 and $7,{ }^{14} \mathrm{C}$-labelled molecular mass markers (in decreasing order of size) bovine serum albumin, ovalbumin, carbonic anhydrase and lysozyme; 2, DNA-free control; 3, pAT153 control (Amersham); 4, pCl341 vector (cat product); 5, pCl411 (the arrows indicate the positions of the transcription and translation products of ORFs 1,2 and 3 with molecular masses of $24.9 \mathrm{kDa}, 6.7 \mathrm{kDa}$ and $12 \mathrm{kDa}$ respectively); $6, \mathrm{pCl} 431$, the chloramphenicol-resistant recombinant plasmid derived from $\mathrm{pCl} 411$ and $\mathrm{pCl} 341$, showing the products of all three ORFs of $\mathrm{pCl} 411$ and the cat product from $\mathrm{pCl} 341$.

\section{Sequence analysis of $\mathrm{pCl} 411$}

Plasmid pCI411 was sequenced to completion on both strands (Fig. 2). It comprises 2926 bp. Three significant open reading frames (ORFs) covering $38 \%$ of the plasmid were identified. ORF1, from position 1638 to 2264 , could encode a peptide of 208 amino acids with a molecular mass of $24.9 \mathrm{kDa}$. ORF 2 begins at nucleotide 2260 , overlaps the ORF1 codon by four base pairs and extends to position 2431. It had the capacity to encode a 56 amino acid peptide with a molecular mass of $6.7 \mathrm{kDa}$. ORF3 extends from position 2444 to 2761 and could encode a 105 amino acid peptide of molecular mass $12 \mathrm{kDa}$. Transcriptiontranslation analysis of pCI411 indicated the presence of proteins of molecular masses corresponding to those predicted (Fig. 3). The three prominent bands in the sample containing pCI411 are also evident in the sample containing the pCI411-pCI341 recombinant plasmid, which also has the product of the pC194 cat gene. The high level of background frequently encountered with the in vitro transcription-translation system is possibly due to the production of truncated derivatives of the larger gene products. All three ORFs have an ATG start codon, show the same orientation and are preceded by identifiable ribosome-binding sites at the consensus distance from the translational start reported for genes of Gram-positive bacteria (van de Guchte, 1991). A putative promoter region is located 261 bases upstream of ORF1. The putative -10 (TCTTAT) and the -35 regions (TGAACA) lie within a stem-loop structure with a calculated free energy of binding, $\Delta G$, of $-25 \mathrm{kcal} \mathrm{mol}^{-1}$ $\left(-104 \cdot 6 \mathrm{~kJ} \mathrm{~mol}^{-1}\right)$. It has been proposed that inverted repeat structures overlapping Rep promoters could constitute a target site for auto-regulation of Rep protein expression in the theta replicating plasmid pIP501 (Brantl \& Behnke, 1992).

Comparison of the three pCI411-encoded proteins with the Swiss-Prot protein sequence databank (EMBL, Heidelberg, Germany) and NBRF-PIR (Washington DC, USA) revealed significant similarity with proteins from Gram-positive replicons. ORF1 showed $46.3 \%$ homology to the replication initiation protein RepB from the Lactobacillus plantarum plasmid pLB4 (Bates \& Gilbert, 1989). There was also significant homology to the replication initiation proteins of pADB201 of Mycoplasma mycoides (41.5\%; Bergemann et al., 1989), pA1 from $L b$. plantarum (28.7\% ; Vujcic \& Topisrovic, 1993) and pE194 from Staphylococcus aureus $(22.2 \%$; Horinouchi \& Weisblum, 1982). ORF2 showed $52 \cdot 1 \%$ similarity to ORF C of pWV01, believed to encode the repressor protein regulating synthesis of the replication initiation protein (Leenhouts et al., 1991). There was no apparent similarity between ORF3 and other DNA or protein sequences in the data banks.

The homology of the translated peptide product of ORF1 to the replication initiation proteins of pLB4, pADB201, pA1 and pE194 argues in favour of pCI411 replicating by the RC mechanism. Where this system operates, a specific target site, the DSO, located upstream of the rep gene is nicked by the replication initiation protein. The sequence 5'-TACTACAACACCCCCCTATGT-3', which was homologous (one mismatch) to the DSO of RC plasmids pE194, pSH71, pLS1 and pWV01, was identified $440 \mathrm{bp}$ upstream of the RepB start codon and is believed to be the DSO of pCI411. The observation that the plasmid construct pCI430 (Table 1 and Fig. 1), which lacks this region, could not replicate in Leuconostoc supports this proposal. ORF2 of pCI411, in addition to exhibiting strong homology to RepC of pWV01, is translationally coupled to ORF1 encoding RepB. In pWV01, pLB4 and pLS1 repressor proteins are also translationally coupled to the replication initiation proteins.

The SSO functions as the initiation site for DNA synthesis on the lagging strand. This site is normally located outside the minimal replicon and its deletion may cause a reduction in copy number, plasmid instability and accumulation of ssDNA intermediates (del Solar et al., 1987). Different sequences representing the lagging strand initiation site have been characterized: sso $A$ (formerly palA, Gruss et al., 1987), ssoU (formerly palU, Bron et al., 1988), ssoT (formerly palT, Devine et al., 1989) and a new type not belonging to these three groups which is highly conserved in plasmids like pLP4 and pLJ1 (Leer et al., 1992). Typical SSOs are palindromic sequences of up to 200-300 bp in length with the potential to form hairpin secondary structures. In addition, all sso $A$ s harbour socalled $\mathrm{RS}_{\mathrm{B}}$ sites at the $3^{\prime}$ base of the stem, containing the 18 bp consensus sequence $5^{\prime}$-AAGTTTTCTCGGCATAAA-3' (Gruss et al., 1987). When pCI411 was examined for such characteristics, a similar sequence with one 
mismatch was located at position 423-440 within a direct repeat and $37 \mathrm{bp}$ downstream of an inverted repeat region (346-360:372-385, $\Delta G-17 \mathrm{kcal} \mathrm{mol}^{-1}\left(-71 \cdot 1 \mathrm{~kJ} \mathrm{~mol}^{-1}\right)$. However, unlike sso $A$ s this region does not contain the consensus sequence 5'-TAGCGT-3' (del Solar et al., 1987) present in the loop of all sso $A \mathrm{~s}$. As no other potential SSO motifs were identified on the plasmid, this region may be the SSO of pCI411.

\section{Additional structural features of pCl411}

Plasmid pCI411 contains two putative site-specific recombination sequences, $\mathrm{RS}_{\mathrm{A}}$ and $\mathrm{RS}_{\mathrm{B}}$ (Fig. 2). These sites have been studied in Staph. aureus plasmids, where they have been shown to be involved in stable cointegrate formation between small plasmids (Novick et al., 1984; Gennaro et al., 1987). The suggested 20 base $\mathrm{RS}_{\mathrm{A}}$ site of pCI411 showed significant homology with that of pE194 (three mismatches); however, a genetic determinant for MOB (mobilization) which is involved in DNA nicking at the $\mathrm{RS}_{\mathrm{A}}$ site in the $\mathrm{pE} 194$ system (Gennaro et al., 1987) was not found on the Leuconostoc plasmid. The plasmid recombination/cointegration system mediated by the MOB-RS $\mathrm{A}_{\mathrm{A}}$ process is common in Staphylococcus and Bacillus, and the existence of MOB- $\mathrm{RS}_{\mathrm{A}}$ complexes has been demonstrated in pLB4 from $L b$. plantarum (Bates \& Gilbert, 1989) and pLAB100 from Lactobacillus bilgardii (Josson et al., 1990). Like $\mathrm{pCI} 411$, an $\mathrm{RS}_{\mathrm{A}}$ region apparently lacking a MOB determinant has been described for plasmid pA1 of Lb. plantarum (Vujcic \& Topisirovic, 1993) and lactococcal plasmid pFX2 (Xu et al., 1991). In these instances it was speculated that, despite the absence of a MOB-determinant on the plasmid, the function may be encoded by the chromosome or a different plasmid in the original host, and hence cointegrate formation leading to conjugative mobilization may still occur. A number of imperfect direct repeats have been identified on pCI411 (Figs 1 and 2) and it is not known what their function, if any, might be. The potential role of all six of the stem and loop structures identified on pCI411 is also uncertain.

\section{Detection of ssDNA intermediates during plasmid replication}

Plasmids pCI411, and the control plasmids pNZ12 and pCI305, were assayed for their ability to produce ssDNA during replication. ssDNA was observed during replication of $\mathrm{pCI} 411$ as was also the case for $\mathrm{pNZ12}$ which has previously been shown to produce ssDNA (Hayes et al., 1991). pCI305, a small theta-replicating plasmid (Hayes et al., 1991) employed as a negative control, did not generate ssDNA (data not shown). These observations strongly suggest that $\mathrm{pCI} 411$ replicates using the $\mathrm{RC}$ mechanism.

\section{Host range and homology of $\mathrm{pCl} 411$ with Leuconostoc sp. plasmids}

To determine whether pCI411 was homologous to other plasmids in various Leuconostoc species, pCI411 was labelled and probed against the plasmid profiles of seven strains of Leuc. lactis and Leuconostoc mesenteroides (Table 1). Under the conditions of the experiment (high stringency) no hybridization was detected between pCI411 and the other Leuconostoc plasmids. pCI431, the $\mathrm{Cm}^{\mathrm{R}}$ derivative of pCI411, was used to transform a number of genera by electroporation. Expression of this $\mathrm{Cm}^{\mathrm{R}}$ gene, which is derived from the staphylococcal plasmid pC194 (Gruss \& Ehrlich, 1989), was previously demonstrated in all the genera chosen for the pCI411 host-range studies. The pCI411 replicon was electroporated into, and shown to function in, Leuconostoc mesenteroides subsp. mesenteroides NCDO2028, Leuconostoc paramesenteroides NCDO1612, Lc. lactis subsp. lactis MG1614, Strep. salivarius subsp. thermophilus A054, B. subtilis DB104 and Lb. casei 20012. The replication functions did not operate in E. coli HB101, suggesting that $\mathrm{pCI} 411$ has a broad host range only among Gram-positive genera. It is, however, interesting that the DNA-directed transcription-translation system, which is based on an E. coli S30 extract, was apparently able to transcribe and translate all three ORFs of pCI411, while the plasmid could not be shown to replicate in this genus.

\section{ACKNOWLEDGEMENTS}

This work was supported by the European Community BRIDGE programme (contract BIOT-CT91-0263). We thank $\mathrm{S}$. Foley for her valuable criticism of this manuscript and $\mathrm{T}$. O'Sullivan for his assistance.

\section{REFERENCES}

Anderson, D. G. \& McKay, L. L. (1983). A simple and rapid method for isolating large plasmid DNA from lactic streptococci. Appl Environ Microbiol 46, 549-552.

Bates, E. E. M. \& Gilbert, H. J. (1989). Characterization of a cryptic plasmid from Lactobacillus plantarum. Gene 85, 253-258.

Bergemann, A. D., Whitley, J. C. \& Finch, L. R. (1989). Homology of Mycoplasma plasmid pADB201 and staphylococcal plasmid pE194. J Bacteriol 171, 593-595.

Birnboim, H. C. \& Doly, J. (1979). A rapid alkaline extraction procedure for screening recombinant plasmid DNA. Nucleic Acids Res 7, 1513-1523.

Boyer, H. W. \& Roulland-Dussoix, D. (1969). A complementation analysis of the restriction and modification of DNA in Escherichia coli. J Mol Biol 41, 459-472.

Brantl, S. \& Behnke, D. (1992). Copy number control of the streptococcal plasmid pIP501 occurs at three levels. Nucleic Acids Res 20, 395-400.

Bron, S., Luxen, E. \& Swart, P. (1988). Instability of recombinant pUB110 plasmids in Bacillus subtilis: plasmid-encoded stability function and effects of DNA inserts. Plasmid 19, 231-241.

Caplice, E., Fitzgerald, G. F. \& Daly, C. (1987). Conjugative transfer of a recombinant proteinase plasmid from Streptococcus lactis to Leuconostoc mesenteroides. FEMS Microbiol Rev 46, P35.

Chassy, B. M. \& Flickinger, J. L. (1987). Transformation of Lactobacillus case $i$ by electroporation. FEMS Microbiol Lett 44, 173-177.

Coffey, A. G., Fitzgerald, G. F. \& Daly, C. (1991). Cloning and characterization of the determinant for abortive infection of bacteriophage from lactococcal plasmid pCI829. J Gen Microbiol 137, 1355-1362. 
David, S. (1992). Genetics of mesopbilic citrate fermenting lactic acid bacteria. PhD thesis, Wageningen Agricultural University.

David, S., Stevens, H., van Riel, M., Simons, G. \& de Vos, W. M. (1992). Letuconostoc lactis $\beta$-galactosidase is encoded by two overlapping grenes. J Bacteriol 174, 4475-4481.

Devine, K., Hogan, S., Higgins, D. \& McConnell, D. (1989). Replication and segregational stability of the Bacillus plasmid pBAA1. I Bacteriol 171, 1166-1172.

Garvie, E. I. (1986). Gram-positive cocci: genus Leuconostoc. In Bergey's Manual of Systematic Bacteriology, vol. 2, pp. 1071-1075. Edited by P. H. A. Sneath, N. S. Mair, M. E. Sharpe \& J. G. Holt. Baltimore: Williams \& Wilkins.

Gasson, M. J. (1983). Plasmid complements of Streptococcis lactis NCDO712 and other lactic streptococci after protoplast induced curing. I Bacteriol 154, 1-9.

Gennaro, M. L., Kornblum, J. \& Novick, R. P. (1987). A site-specific recombination function in Staphylococcus aureus plasmids. J Bacteriol 169, 26012610

Gruss, A. \& Ehrlich, S. D. (1989). The family of highly interrelated single-stranded deoxyribonucleic acid plasmids. Microbiol Rev 53, 231-241

Gruss, A., Ross, H. \& Novick, R. (1987). Functional analysis of a palindromic sequence required for normal replication of several staphylococcal plasmids. Proc Natl Acad Sci US A 84, 2165-2169.

van de Guchte, M. (1991). Heterologous gene expression in Lactococcus lactis. $\mathrm{PhD}$ thesis, University of Groningen.

Hastings, J. W., Sailer, M., Johnson, K., Roy, K. L., Vederas, J. C. \& Stiles, M. E. (1991). Characterization of Leuconin A-UAL 187 and cloning of the bacteriocin gene from Leuconostoc gelidium. J Bacteriol 173, 74917500 .

Hayes, F., Daly, C. \& Fitzgerald, G. F. (1990). Identification of the minimal replicon of Lactococcus lactis subsp. lactis UC317 plasmid pCI305. Appl Environ Microbiol 56, 202-209.

Hayes, F., Vos, P., Fitzgerald, G. F., de Vos, W. M. \& Daly, C. (1991). Molecular organization of the minimal replicon of the narrow host-range lactococcal plasmid pCI305. Plasmid 25, 16-26.

Horinouchi, S. \& Weisblum, B. (1982). Nucleotide sequence and functional map of $\mathrm{pE194}$, a plasmid that specifies inducible resistance to macrolide, lincosamide and streptogramin type B antibiotics. J Bacteriol 150, 804-814.

Josson, K., Soetaert, P., Michiels, F., Joos, H. \& Mahillon, J. (1990). Lactobacillus hilgardii plasmid pLAB100 consists of two functional cassettes commonly found in other gram-positive organisms. $J$ Bacteriol 172, 3089-3099.

Leenhouts, K. J., Tolner, B., Bron, S., Kok, J., Venema, G. \& Seegers, J. F. M. S. (1991). Nucleotide sequence and characterization of the broad-host-range lactococcal plasmid pWV01. Plasmid 26, 55-66.
Leer, R., van Luijk, N., Posno, M. \& Pouwels, P. H. (1992). Structural and functional analysis of two cryptic plasmids from Lactobacillus pentosus MD353 and Lactobacillus plantarum ATCC 8014. Mol \& Gen Genet 234, 265-274.

Macrina, F. F., Kopeco, D. J., Jones, K. R., Ayers, D. J. \& McCowen, S. M. (1978). A multiple plasmid-containing Escherichia coli strain: a convenient source of size reference plasmid molecules. Plasmid $\mathbf{1}$, $417-420$

Mathieu, F., Sudirman-Suwandhi, I., Milliere, J. B. \& Lefebvre, G. (1993). Mesenterocin 52, a bacteriocin produced by Leuconostoc mesenteroides ssp. mesenteroides FR 52. J Appl Bacteriol 74, 372-379.

Novick, R. P., Projan, S. J., Rosenblum, W. \& Edelman, I. (1984). Staphylococcal plasmid cointegrates are formed by host- and phage-mediated general rec systems that act on short sequences of homology. Mol \& Gen Genet 195, 374-377.

Sambrook, J., Fritsch, E. F. \& Maniatis, T. (1989). Molecular Cloning: a Laboratory Manual, 2nd edn. Cold Spring Harbor, NY: Cold Spring Harbor Laboratory.

Sanger, F., Nicklen, S. \& Coulson, A. R. (1977). DNA sequencing with chain-terminating inhibitors. Proc Natl Acad Sci USA 74, 5463-5467.

Slos, P., Bourquin, J.-C., Lemoine, Y. \& Mercenier, A. (1991). Isolation and characterization of chromosomal promotors of Streptococcus salivarius subsp. thermophilus. Appl Environ Microbiol 57, 1333-1339.

del Solar, G. H., Puyet, A. \& Espinosa, M. (1987). Initiation signals for the conversion of single stranded to double stranded DNA forms in the streptococcal plasmid pLS1. Nucleic Acids Res 15, $5561-5580$

Southern, E. M. (1975). Detection of specific sequences among DNA fragments seperated by gel electrophoresis. J Mol Biol 98, 503-517.

Terzaghi, B. E. \& Sandine, W. E. (1975). Improved medium for lactic streptococci and their bacteriophages. Appl Microbiol 29, 807-813.

Vehmaanperä, J. (1989). Transformation of Bacillus amyloliquefaciens by electroporation. FEMS Microbiol Lett 61, 165-170.

Vujcic, M. \& Topisirovic, L. (1993). Molecular analysis of the rolling-circle plasmid pA1 of Lactobacillus plantarum A112. Appl Environ Microbiol 59, 274-280.

Xu, F., Pearce, L. E. \& Yu, P.-L. (1991). Genetic analysis of a lactococcal plasmid replicon. Mol \& Gen Genet 227, 33-39.

Yang, X. \& McFadden, B. A. (1993). A small plasmid, pCA2.4, from the cyanobacterium Synechocystis sp. strain PCC 6803 encodes a Rep protein and replicates by a rolling circle mechanism. J Bacteriol 175 , 3981-3991

Received 21 December 1993; revised 24 March 1994; accepted 31 March 1994. 